\section{AI \& SOCIETY}

The Journal of Human. Centred and Machine Intelligence Special Issue: Genetic

Technologies and Animals

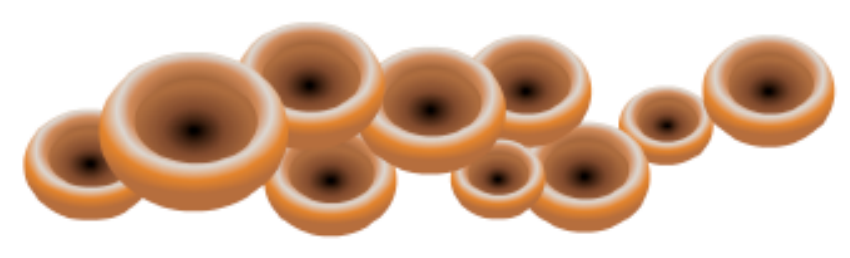

Table of Contents Authors Preface Intro Credits

\title{
Leonardo choice: the ethics of artists working with genetic technologies
}

\author{
Carol Gigliotti \\ Received: 10 February 2005 / Accepted: 1 June 2005 \\ Springer-Verlag London Limited 2005
}

Abstract: Working with current methodologies of art, biology, and genetic technologies, the stated aims of artists working in this area include attempts both to critique the implications and outcomes of genetic technologies and to forge a new art practice involved in creating living beings using those technologies. It is this last ambition, the development of a new art practice involved in creating living beings, that this essay will particularly take to task by questioning the ethics of that goal and the uses of biotechnology in reaching it.

Keywords: Animals, Biogenetics, Ethics, Aesthetics, Ecocentricism, Anthropomorphism, Animal rights, New media

Although its source may well be apocryphal, the following quote has been attributed to Leonardo da Vinci, "I have from an early age abjured the use of meat, and the time will come when men such as I will look upon the murder of animals as they now look upon the murder of men" (Preece, 2002, 93).1 While da Vinci may not have said exactly that, his compassion for animals is well documented in his notebooks and several sources cite his vegetarianism (Clark, 1977, 45). The notebooks contain numerous references to his shock and disdain for man deliberate choice in abusing the other animals, many of whom provide him with food and labor:

Of candles made of beeswax,

[The bees] give light to divine service and for this they are destroyed.

Of asses

Here the hardest labor is repaid by hunger and thirst, pain and blows, goads and curses, and loud abuse.

Of a fish served with its roe 
Endless generations of fish will be lost because of the death of this pregnant one.

Of slaughtered oxen

Behold - the lords of great estates have killed their own laborers (quoted in Kellen 1971, 78- 79).

Vasari in describing Leonardo' s exemplary character tells us how Leonardo' s compassion for animals was such that he bought caged birds merely to set them free (Turner, 1993, 62). Vasari, however, also has a very young Leonardo composing a painting of a monster (possibly a Medusa) modeled on dead "lizards, grasshoppers, serpents, butterflies, locusts, bats, and other strange animals of the kind" he had brought to his room. An additional story by Vasari of a much older Leonardo in Rome, describes how the artist spent his time, much to the chagrin of Pope Leo X:

"To the back of a very odd-looking lizard that was found by the gardener of the Belvedere he attached with a mixture of quicksilver some wings, made from the scales stripped from other lizards, which quivered as it walked along. Then, after he had given it eyes, horns and a beard he tamed the creature, and keeping it in a box, he used to show it to friends and frighten the life out of them." (quoted in Turner, 62)

Much of Vasari' s information about Leonardo is second hand and some of it is more than likely to have been invented (Turner, 55 268 ), but, together with Leonardo $>$ s notebooks, these tales of Leonardo give us some appreciation of the conflicting priorities that may have existed in Leonardo $>\mathrm{s}$ attitudes towards animals. He was compassionate toward the plight of animals used solely for human purposes, while at times using animals himself for his own purposes. A painter, a scientist, a naturalist, a technologist, a prophet, Leonardo was both an exemplar of his time and ahead of it.

These preoccupations of Leonardo are reflective of ethical issues brought up by artists working with genetic technologies involving bacteria, plants, and animals. Many of these artists are seen or see themselves as descendents of Leonardo and his abilities to cross the disciplines of art and science. It is no accident that the leading publication of such crossover activity for the last 36 years has been the influential "Leonardo: Journal of the International Society of the Arts, Science and Technology." Held (2001), Curator of Gene(sis): Contemporary Art Explores Human Genomics, an exhibit traveling from 2002 to 2004, introduces the exhibit in this way:

"As artists take up the tools and materials of genetic and genomic research, their experimental reflections are changing our notions of artistic practice. Many artists function as researchers, engaged in nonhypothesis- driven, open-ended investigations. Their studios are laboratories for this experience-based inquiry. In addition, artists such as Eduardo Kac, Critical Art Ensemble, Paul Vanouse, Joe Davis, Tissue Art and Culture, Jill Reynolds, In igo Manglano-Ovalle, and Justine Cooper, to name just a handful, regularly use biological materials in their work. In some cases, artists are creating new life forms and releasing them into the environment."(p. 4) 
Working with current methodologies of art, biology, and genetic technologies, the stated aims of artists working in this area include attempts both to critique the implications and outcomes of genetic technologies and to forge a new art practice involved in creating living beings using those technologies.

It is this last ambition, the development of a new art practice involved in creating living beings, that this essay will particularly take to task by questioning the ethics of that goal and the uses of biotechnology in reaching it. Doing so has proven to be a contentious activity, involving as it does discourse about both artistic and scientific practice, each bringing along its own linguistic and conceptual assumptions, metaphorical, and otherwise. Participants in this debate have come from what some may consider to be both "inside" and "outside" the art world: the artists themselves, curators, critics, art theorists, philosophers, cultural and political critics, theologians and scientists, and the general public.

Many of these participants, wherever their disciplinary reference-point might be, see art as one of the few environments left where uncensored thought is not only condoned, but also encouraged. As Efimova (2003), Associate Curator of the Berkeley Art Museum presentation of Gene(sis), says in her introductory essay, "...experimental art remains one of the few enclaves where imaginative, impractical, non-mundane thinking is still tolerated." (p.1)

\section{Is thinking in art always radical?}

The idea that art is a last bastion for radical thinking has frequently been used as a rationale for this new art practice. In an essay included in The Eighth Day: The Transgenic Work of Eduardo Kac, Machado (2003) argues this point. He contends that critiques of biotechnologies tend to take a "conservative bias" or "even dogmatic interdictions of religious order." He sees: "The more experimental and much less conformist sphere of art with its emphasis on creation, by means of genetic engineering, of works which are simply beautiful, not utilitarian or potentially profit making..." (p. 94) as conducive to more sophisticated discussion about genetics as well as science and technology in general. He adds, however, one of the benefits of Kac $>$ s work, The Eighth Day, is to develop science and technology "away from the unproductive dichotomy of good and bad, right or wrong, and toward a confrontation of the whole of its complexity." (p. 95)

Two assumptions are at work in these statements by Machado and in much of the writing by both artists and critics about artists working with genetic technologies. The first assumption is that thinking in art is consistently experimental and non-conformist. While one may assume that to be true, based on some historical precedents, the assumption does not insure that all thinking emerging from art is necessarily radical. The second assumption concerns the idea that a confrontation with the complexity of a topic or issue precludes the necessity of confronting ethical choices embedded in that complexity. On the contrary, one of the main reasons for understanding complexity is the insight it may offer to ethical choice. I highlight the limits of these two assumptions because their uncritical acceptance muddies the discussion of two aspects pivotal in discourse surrounding the ethics and aesthetics of a new art practice involving living beings. 
These two aesthetic aspects are most clearly delineated by art critic Bureaud (2002) in an issue of artpress that included seven essays and a "dossier" on "art bio(techno)logique." She summarizes the discourse around "biological art" as ranging from technical practices involving biological and biotechnological methods to contexts dealing with related human-centered social, political, environmental and ethical issues to human-based perspectives on immortality. Bureaud makes the point, however, that while these perspectives are essential to understanding and evaluating these works, "...analysis often fails to get as far as their artistic or aesthetic aspects." (p. 38) While this implies that artistic or aesthetic aspects will be discussed separately from the ethical aspects of this work, Bureaud describes among the seven aesthetic aspects she has observed in this growing body of work, two characteristics or orientations, one can only see as inextricably entwined with ethical perspectives.

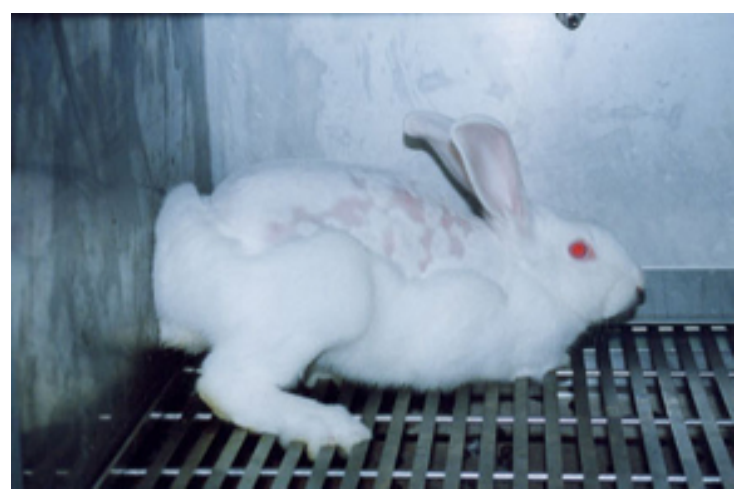

Rabbit with skin removed

Credit: None

The first is an approach she calls the "anti-anthropocentric art of the continuum" including the semi-living (as in Tissue Culture and Art Projects) and transgenic organisms (as in projects by Eduardo Kac). She describes this approach as emphasizing the "permeability of the frontiers between species, the continuity that goes from the non-living to the different degrees of complexity in life forms." (p. 38)

Catts and Zurr (2003, 2004), artists involved in Tissue Culture and Art Projects, utilize the idea of "a continuum of life" as oppositional to an anthropocentric worldview:

"... we argue that the underlying problem concerned with the manipulation of life is rooted in the perceptions of humans as a separated and privileged life form, a perception inherited in the West from the Judo-Christian-and Classical worldviews. This anthropocentricism is distorting society' $\mathrm{s}$ ability to cope with the expanding scientific knowledge of life. Further this cultural barrier in the continuum of life between the human and other living systems prejudices decisions about manipulations of living systems." (p. 2) 
This confusing statement can be read as both critique and support of the historic values of anthropocentrism leading to the instrumentation and destruction of living systems. Catts and Zurr, themselves, point out that much of what they are saying and doing is contradictory and this statement and much of the rest of the essay, from which it is excerpted, is evidence of this. Although they claim that their hope is to challenge "long held beliefs" about the perceived barrier between humans and other living beings, they see their involvement in actually manipulating life as "highlighting the inconsistency of the still prevalent view of the dominion of man." (p.3)

They acknowledge the paradoxical quality of their position:

"...on one hand we attempt to break down specism and make humans part of a broader continuum. On the other hand, we artists-humans, are using (abusing?) our more privileged position to technically manipulate an aesthetic experiment." (17)

They insist, however, "...only when humans realize that they are a part of the continuum of life will manipulating life not be as alarming as it now seems." (p. 17)

The absurdity of this claim is hard to miss. Humans have been manipulating animal life with impunity for thousands of years. Most do not find it alarming, but customary. If, as Zurr and Catts claim, their goal is to encourage people to understand the distortions a human centered view causes in recognizing the continuum of life, more manipulation of life forms will most certainly not contribute to that project, but only serve to reinforce it.

Kac (2000) references an anti-anthropocentric approach in his essay, "GFP Bunny:"

"Rather than accepting the move from the complexity of life processes to genetics, transgenic art gives emphasis to the social existence of organisms, and thus highlights the evolutionary continuum of physiological and behavioral characteristics between the species." (p. 111)

Inherent contradictions appear when reading these quotes in the context of Kac $>$ s transgenic work and his stated goals of "...a new art form based on the use of genetic engineering to transfer natural or synthetic genes to an organism, to create unique living beings." (p. 101) Others have questioned these contradictions in essays on Kac $\geqslant$ s work. Hayles (2000) asks about Kac $\geqslant$ s Gene(sis): "Does Kac $>$ s intervention in the genetic sequences of bacteria contest the notion that humans have dominion or reinforce it? The ambiguity inheres in any artistic practice that uses the tool of the master to gain perspective on the master s house." (p. 86)

Hayles sees the usefulness this approach might have for imagining that same drive for domination and control executed upon the future of the human. But what of the animals who currently exist under that drive? Seen through the lens of transgenic art, what future can we imagine for them?

Baker (2003), in one of the most thoughtful essays on Kac $>_{s}$ work to date, enlists Derrida $\rangle_{s}$ investigations of the human responsibility to the non-human animal to help in understanding 
Kac s work. Derrida (2002), in "The animal that therefore I am," relates how in the last 200 years "...the traditional forms of treatment of the animal have been turned upside down by the joint developments of zoological, ethological, biological, and genetic forms of knowledge and the always inseparable techniques of human intervention with respect to their object, the transformation of the actual object, its milieu, its world, namely the living animal." (p. 394)

Derrida describes this as "violence that some would compare to the worst cases of genocide." While Kac judges the procedures he uses to be safe because they have been regularly employed on mice and rabbits since 1980 and 1985, respectively, Baker (2003) says, "...that is precisely the technology that has led to an increase in the numbers of animals currently subjected to laboratory experiments." (p. 36)

And, in fact, the best estimate of current use of animals used in research in the US is 20 million, and about two million in Canada (Mukerjee 1997). According to more recent sources, however, worldwide animal use was estimated to be between 60 and 85 million animals in the early 1990s. (Rowan 1995) And though the use of animals in experimentation has decreased slightly over the last 40 years due to the diligence and commitment of a vast network of animal welfare and animals rights organizations, "...the impact of genetic engineering on animal use should be carefully monitored, given its potential to reverse the decreases in animal use seen during the 1980s and 1990s" (Salem and Rowan, 2003)

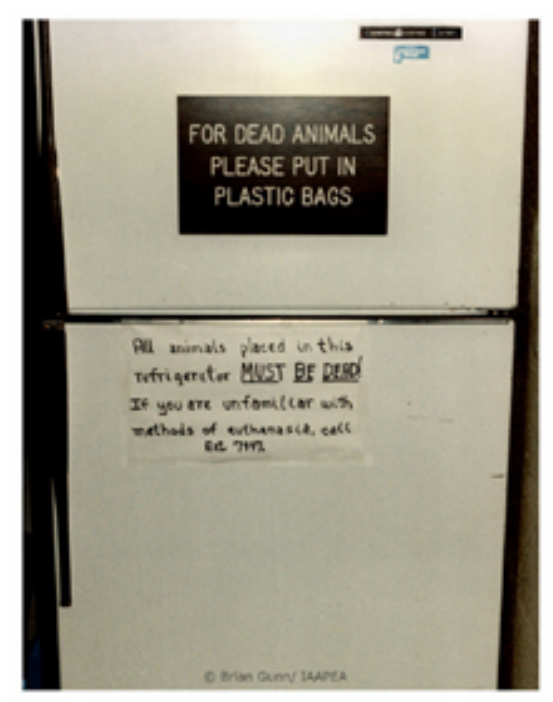

Dead animal refrigerator

Credit: Brian Gunn/IAAPEA

How, then, do these artists see their goal of a new art practice of creating life forms as part of a world view that is anti-anthropocentric, when in fact it continues along the very traditional, conformist, and conservative paths along which are littered the bodies and lives of millions of animals? 


\section{Anthropocentrism, ecocentrism, and animal life}

A more thorough examination of the original ideas and goals of an antianthropocentric worldview and associated sciences, rather than supporting the new art practice of creating life forms, allows the weakness of these artists' arguments and practice to come into view. In addition, in at least these instances, standard ideas about the dominant role played by humans are being reinforced while the truly radical notions of bio-centricism are finding support in other places.

C. Gigliotti

School of Design, Emily Carr Institute of Art and Design, 1399

Johnston Street, Vancouver, BC Canada V6H 3R9

E-mail:

gigliott@eciad.ca www.carolgigliotti.net

Tel.: +1-604-8443800

Fax: +1-604-8443801

AI \& Soc (2005) DOI 10.1007/s00146005-0003-8

Special Issue:

Genetic

Technologies and Animals

AI and Society

VOLUME 20.1

January 2006
While Kac references H.R. Mantura, and Zurr and Catts mention the work of Lynn Marguilas and James Lovelock, the wealth of material on environmental ethics from which ideas about bio-centric worldviews emerge, both in philosophy and practical ecology, have increased tremendously in the last 30 years. An important component of these truly radical worldviews exists in thinking of the telos of an organism, in the Aristotelian sense of the term, and can be roughly understood as the fulfilled state or end or goal of the organism. A helpful approach is to concentrate on the distinction between instrumental value, which is what we traditionally see the natural world as possessing, and intrinsic value. Taylor (1986) in his book, Respect for Nature: A Theory of Environmental Ethics develops a bio-centered or life centered, as opposed to anthropocentric or human- centered, environmental ethics, as well as arguing that all living organisms possess intrinsic worth. What Taylor and others like him are advocating is a "... world order on our planet in which human civilization is brought into harmony with nature." (p. 308) This goal, however, is built upon cultures in which "...each carries on with its way of life within the constraints of the human ethics of respect for persons." (p. 308)

Unlike some arguments based on a "deep ecology" in which a conception of individual organisms having inherent worth is not included, this understanding of environmental ethics makes integral links to necessary changes in social, political, and economic justice on a planetary scale. These changes would include the elimination of all sentient beings in any form of experimentation. As Taylor admits, these changes would require a profound moral reorientation, and the first step would be an "inner change in our moral beliefs and commitments." Respect for and consideration of the intrinsic worth of individuals of any species, far from being disconnected to these changes in our moral commitments to the human species, is fundamental to altering current compulsions for ways of life inherently devastating to much of the planet and its inhabitants. Shiva (2000) argues, "The emerging trends in global trade and technology work inherently against justice and ecological sustainability. They threaten to create a new era of bio-imperialism, built on the impoverishment of the Third World and the biosphere." (p. 25) These trends threaten both ecological and cultural diversity. Shiva cites two root causes for the West 3 s adherence to these obviously negative compulsions:

"The first arises from the 'empty- earth' paradigm of colonization, which assumes that ecosystems are empty if not taken over by Western industrial man or his clones. This view threatens other species and other cultures to extinction because it is blind to their existence, their rights and to the impact of the colonizing culture. The second cause is what I have described as monoculture of the mind: the idea that the world is or should be uniform and one-dimensional, that diversity is either disease or deficiency, and monocultures are necessary for the production of more food and economic benefits." (p. 26)

For Shiva, genetic technologies are turning life, or biology, into "capitalism ${ }_{\mathrm{s}}$ lastest 
frontier."(p. 28) She convincingly reasons, however:

"There is ...one problem with life from the point of view of capital. Life reproduces and multiplies freely. Living organisms self-organizes and replicate. Life?s renewability is a barrier to commodification. If life has to be commodified, its renewability must be interrupted and arrested." (p. 30)

This is being accomplished by industrial breeding, genetic engineering, and patent and intellectual property rights. Shiva, like Taylor, eloquently calls for a major shift in thought, referring to genetic engineering as based on genetic reductionism:

"A shift in the paradigm of knowledge from a reductionist to a relational approach is necessary for both biological and cultural diversity. A relational view of living systems recognizes the intrinsic worth of all species protects their ecological space and respects their self-organizational, diverse, dynamic, and evolving capacities." (p. 129)

The fundamental goals for manipulating nature, at any level, are always grounded in human interest. Attempts by artists to make the case for biogenetic art involving living matter or beings, by and large, have come from a truly nonradical worldview, one that still posits human beings as the center and rationale of all endeavors. This should not be surprising, since this anthropocentric viewpoint matches that of both past and current genetic research upon which this art is based. Using living non-humans in experiments or for other human purposes is a generally accepted practice, one not often questioned within the discourses of science or, for that matter, within the discourses of art.2 The worldview upon which these activities rest sees all of nature as available for human intervention.

Although the stated aims of some artists involved in these discourses are to question the anthropocentric standpoint while at the same time using the tools, methods, and assumed ideologies of biogenetics, the reality of animal use in both biotechnology in general, and in biogenetic art forms specifically, can only highlight in this work a fundamental misunderstanding of what a real commitment to anti-anthropocentric aims might mean. And it is precisely at this point where artistic practice using living beings falls short of any contribution to those aims.

\section{Theories of aesthetics and ethics and the realities of animal life}

The second aesthetic aspect Bureaud mentions that is linked to ethical perspectives is "an aesthetics of attention and responsibility." Both Zurr and Catts and Eduardo Kac, insist that ethical questions are central to their aesthetic concerns. They have discussed at some length how their use of living or semiliving beings is included in that "aesthetics of care." 3 All three, however, also insist that their art practice of creating living beings offers as Kac (2000), claims "important alternatives to the polarizing debate $>$ about genetic engineering, replacing dichotomy with "ambiguity and subtlety." (p. 1) Catts and Zurr (2003, 2004) claim artists involved with this new art form are

"...manipulating life and $>$ inserting life into new contexts including the art galleries. By that they are forcing the audience to engage with the living artwork and to share the consequences/responsibilities involved with the 
manipulation/creation of life for artistic ends." (p. 2)

Some critics, particularly Baker in discussion about Kac $>$ s transgenic work, acknowledge the dichotomy between Kac using the techniques of animal experimentation for biotechnological investigations and his emphasis on responsibility that does not "treat an animal as an object, be it an art object or an object of any kind."4

Comparing Kac and Derrida, Baker (2003) says:

"Kac, with similarly serious intentions, engages with the animal through techniques that strike many people as meddlesome, invasive and profoundly unethical." (29)

Baker believes that a more detailed reading of the connection between this engagement of Kac ${ }_{\mathrm{s}}$, the concern of Derrida with "how to do philosophy by means of a prolonged and serious meditation on his relationship with the cat who shares his home" (p. 32) is necessary. Baker sees the value of the comparison of the two thinkers in what it may tell us about the "relation of intentions to actions in both ethics and aesthetics." (p. 29) I agree, but for somewhat different reasons. Both Kac and Derrida see the animal, through very thick filters, and both have disconnected their actions from their intentions. The goal for each is not an understanding of the animal for itself, but for a human-centered reason. Derrida sees the animal through the filter of "doing philosophy" and the impossibility of an excessive responsibility to the animal in the present culture, while Kac sees the animal through the filter of an acceptance of the inevitability of a biotechnological future in which his goal of the new art practice of creating living beings makes sense. Derrida (1991), even as he attempts to outline an "excessive" responsibility that includes the non-human, builds a case for the impossibility of acting on that responsibility:

"[A] pure openness to the [O]ther is impossible and certainly in this culture. We can no more step out of carnophallogocentrism to some peaceable kingdom than we can step out of metaphysics. Put another way, a violence of a sort, 'eating $[\mathrm{O}]$ thers,' is not an option, but a general condition of life, and it would be a dangerous fanaticism (or quietism) to suppose otherwise. The issue is not whether we eat, but how." (p. 115)

Unfortunately, though Derrida' s intentions are to deconstruct the general scheme of dominance in Western metaphysics and religion, he disregards something that might be helpful in being able to see animals as other than food, tools, or entertainment. He does not seem to be able to take even the fundamental step of vegetarianism. His reasons for this and arguments against those reasons are the stuff of a much longer essay, but suffice it to say, that a sense of inevitability and an inability to see or imagine outside that scheme of dominance seems to play a role in Derrida disconnection between his intentions and actions. While his equivocation towards vegetarianism "seems to rest on the restricted, cautious assessment of its significance; one which would allow vegetarians to buy good conscience on the cheap," he misses the opportunity in a committed ethical vegetarianism, and even better veganism, for what Wood (1999) calls a "motivated possibility of response." As Wood so forcefully puts it:

"Carnophallogocentrism is not a dispensation of being toward which resistance is futile; it is a mutually reinforcing network of powers, schemata of domination, and investments that has to reproduce itself to stay in existence. Vegetarianism is not just about substituting beans for beef; it is- at least potentially- a site of proliferating resistance to that reproduction." (p. 32) 
The disconnection between actions and intentions is less overt in the case of Kac. Kac' s ambivalence towards the inevitability of a biotechnological future, and in some cases his welcoming of it, clouds our reception of what his inner thoughts might be about his uses of living beings, even as he critiques the Western philosophical canon on which those uses are based. Lestral (2002) touches briefly on why this might be so in general for artists working in this vein. "We must also take into account the inglorious possibility that these artists are being manipulated - and not necessarily consciously either - by technologists and multinationals; that they are serving to legitimize practices that our cultures otherwise find it hard to accept." (p. 45) While Lestral backs away from this conclusion, for one that he finds 7 more reasonable 2 that sees these artists as doing what artists have always done by exploring practices of their period, he questions if art can play the role of being "critical."

And while Kac's work has been effective in highlighting the complex quality of this society' $\mathrm{s}$ involvement with biotechnology, his acceptance of a biotechnological future and his use of techniques that objectify the animal, frustrate a response that seeks to confront ethical choices embedded in that complexity and also frustrates imagining alternatives. Put another way, one cannot say they object to treating an animal as an object of any kind, and then use the very techniques of objectification to create an animal for the purpose of continuing this objectification in the form of a new art practice. What value does $>$ confronting complexity have if it obscures insight into a "possibility of response?"

Catt and Zurr' s work suffers from the same burden, though they appropriate arguments from two of the most important animal rights philosophers, Regan (1983) and Singer (1975) to support their work with tissue cultures. Taking liberties with both philosophers $\vec{\theta}$ positions, they use Singer ${ }_{\text {s }}$ utilitarian position that would allow experiments on animals if the experimenters also would be willing to use humans at an equal or lower level of consciousness, rather than Regan individualist deontological position that makes a case for an end to all experimentation of non-humans. Regan argues that animals are the "subject-of a-life" and thus have inherent value:

"A being that is a subject-of-a-life will: have beliefs and desires; perception, memory, and a sense of the future, including their own future; an emotional life together with feelings of pleasure and pain; preference-interests and welfareinterests; the ability to initiate action in pursuit of their desires and goals; a psychological identity over time; and an individual welfare in the sense that their experiential life fares well or ill for them, logically independently of their utility for others, and logically independently of their being the object of anyone else' s interests. Those who satisfy the subject-of-a-life criterion themselves have a distinctive kind of value inherent value and are not to be viewed or treated as mere receptacles." (p. 243)

And in contrast to Singer' s utilitarian interpretation of formal justice, and in this case Catt and Zurr s interpretation as well, Regan argues for an acceptance of the respect principle in relation to those who are subject-of-a-life:

"We cannot justify harming them merely on the grounds that this will produce an optimal aggregate balance of intrinsic goods over intrinsic evils for all concerned. We owe them respectful treatment ... because justice requires it." (p. 261) 
Catts and Zurr (2003, 2004), however, seem to be filtering any understanding of their commitments and "care" for non-human beings through their fascination with the techniques of biotechnology and a confounding of what might constitute intrinsic good or evil for the animals involved in genetic technologies. Their project, "Disembodied Cuisine" investigating "the possibility of eating victimless meat by growing semi-living steaks from a biopsy taken from an animal while keeping the animal alive and healthy" (p. 13) is an example of this. They believe:

"That by the creation of the new class of semi-living /partial life we further shift/blur/problematise the ethical goalpost in relation to our (human) position in the continuum of life. The discussion that being generated regarding the rights of the semi-living will draw attention to the conceptual frameworks in which we humans understand and relate to the world." (17)

And to this they add: "To manipulate life is to be at home with the other that can be anything within this continuum." (p. 17) Once again, one cannot say they do not relate to the living or semi-living as an object and then manipulate that living/semi-living being as an object. Why continue to use animals in any form as food if you wish to question the traditional view of the non-human? The continuation of such a program can only make suspect their stated goals of a "humble attempt of ethical consideration which goes beyond the ' I' the 'You ' and even the ' Human ' (as much as our humanness ' burden ' enables us)." (p. 18 19)

In light of the urgency of the future of the ecosystem' s integrity, of which biotechnology is increasingly playing a large role, and the millions of our fellow creatures whose lives we are destroying in that process, it is important to ask, what does art contribute to that future? What responses come from those contributions? The continuation of art practices of creating lifeforms through bio technological means can only serve to implicate these practices, and artists who are involved in them, in contributing to a worldview that still values particular human needs above all else. This worldview, based as it is on the control and manipulation of nature, will continue to blind us to the more radical transformation of acknowledging that we have always been transgenic. The practices of biotechnology are misuses of that knowledge. Far more radical and creative responses to that fact may be based upon a number of increasingly influential ideas from broader areas of thought: the revolutionary idea in cognitive ethology that all living beings are equally gifted with their own worldview or a bio centered environmental ethics that sees all living organisms possessing intrinsic worth. Appreciating and protecting the biodiversity existing already in the natural and cultural world, or what we have left of it, is part of this learning curve. Additionally, imaginative responses might be based on the enormous amount of thinking now going on in philosophy about the status of the animal. Reminiscent of Regan' s The Case for Animal Rights, another more recent philosophical argument along these lines, is cogently outlined by Italian philosopher, Cavalieri (2003). It is supported by much of the information and research from cognitive ethology and studies of the mind, but also rests on the major point, similar to earlier debates on the status of women and slaves, that: "...the shift from the condition of objects to that of subjects of legal rights does not appear as a point of arrival but rather as the initial access to the circle of possible beneficiaries of that ' egalitarian plateau ' from which contemporary political philosophy starts in order to determine any more specific individual right." (p. 142) This shift calls for a further reorganization of society, similar to ongoing shifts concerning human rights, requiring the abolition of the status of animals as property or assets and the prohibition of all practices made possible by that status. This would, of course, include the prohibition of animal experimentation of all kinds. Describing her 
argument as neither contingent nor eccentric but the "necessary dialectical derivation of the most universally accepted among contemporary ethical doctrines - human rights theory," Cavalieri insists the argument demands a commitment to not only avoiding participating in, but also demands, a commitment to opposing discrimination. Denying these demands would subvert "...not merely what is right, but the very idea of justice." (p. 143)

Whether to continue to put energies toward a new art form of creating living beings or to commit to a more radical worldview that responds to the urgent cries of a disappearing natural world is the choice before the contemporary artist.

\section{Notes}

1 The quote is actually from a work of fiction written by Merijkowsky in the 1920s Romance of Leonardo da Vinci.

2 There are, of course, exceptions to this statement, including artists Sue Coe, Mark Dion, Julian Schanbel, and Britta Jaschinski, among others.

3 This phrase comes from the title "The Aesthetics of Care?" a symposium presented by SymbioticA and The Institute of Advanced Studies, University of Western Australia. August 5 2002 at Perth Institute for Contemporary Arts. Catts and Zurr and their Tissue Culture and Art Project are hosted by SymbioticA - The Art and Science Collaborative Research Lab.

4 "Interview with Eduardo Kac" Interview conducted online, with questions posted to the Genolog website, July September 2000 http://www.ekac.org/genointer.html, pp. 3- 4.

\section{References}

Baker S (2003) Philosophy in the Wild? In: Britton and Collins (eds) The Eighth Day: the transgenic art of Eduardo Kac, Institute for Study in the Arts, Tempe, Arizona

Bureaud A (2002) The ethics and aesthetics of biological art. Trans C Penwarden artpress $276: 38$

Catts O, Zurr I $(2003,2004)$ The ethical claims of bioart: killing the other or self-cannibalism. Aust NZ J Art: Art Ethics Double Issue 4(2) and 5(1):167-188. Page numbers are from http://www.tca.uwa.edu.au/publications/TheEthicalClaimsofBioart.pdf

Cavalieri P (2003) The animal question: why non-human animals deserve human rights. Oxford University Press, New York

Clark K (1977) Animals and men: their relationship as reflected in western art from prehistory to the present day. Thames \& Hudson, London

Derrida J (1991) 'Eating well,' or the calculation of the subject. In: Cadava, Connor, Nancy (eds) Who comes after the subject? Routledge, New York London

Derrida J (2002) The animal that therefore I am (more to come), trans. David Wills, Critical Inquiry, 28(Winter) 
Efimova A (2003) Introduction: Gene(sis): contemporary art explores human genomics. Berkeley Art Museum http://www.bampfa.berkeley.edu/resources/exhibit_archive/index.html

Hayles NK (2000) Who is in control here? Meditating on Eduardo Kac' s transgeneic work. In: Britton and Collins (eds) The eighth day: the transgenic art of Eduardo Kac. Institute for Study in the Arts, Tempe, Arizona

Held R (2001) Gene(sis): a contemporary art exhibition for the genomic age In: Gene(sis): Contemporary Art Explores Human Genomics http://www.gene-sis.net/new_essays.html

Kac E (2000) GFP Bunny. In: Dobrila P, Kostic A (eds) Eduardo Kac: telepresence, biotelematics, and transgenic art. Kibla, Maribor, Slovenia

Kellen E (ed) (1971) Fantastic tales, strange animals, riddles, jests and prophecies of Leonardo da Vinci. Thomas Nelson, New York

Lestel D (2002) The artistic manipulation of the living. Trans C Penwarden artpress 276:45

Machado A (2003) Towards a transgenic art. In: Britton and Collins (eds) The Eighth Day: the transgenic art of Eduardo Kac. Institute for Study in the Arts. Tempe, Arizona Mukerjee M (1997)

Mukerjee M Trends in animal research. Scientific American

Preece R (2002) Awe for the tiger, love for the lamb. UBC Press, Vancouver, BC

Regan T (1983) The case for animal rights. University of California Press, Berkeley

Rowan A (1995) Replacement alternatives and the concept of alternatives. In: Goldberg, van Zutphen (eds) The world congress on alternatives and animal use in the life sciences: education, research, testing. Mary Ann Liebert, New York

Salem DJ, Rowan AN (eds) (2003) The state of the animals II. Humane Society Press, Washington, DC

Shiva V (2000) Tomorrows biodiversity. Thames and Hudson, London

Singer P (1975) Animal liberation. Avon Books, New York

Taylor PW (1986) Respect for nature: a theory of environmental ethics. Princeton University Press, Princeton, NJ

Turner AR (1993) Inventing Leonardo. Knopf, New York

Wood D (1999) Comment ne pas manger Deconstruction and Humanism. In: Steves (ed) Animal others: on ethics, ontology and animal life. State University of New York Press, Albany 